\title{
https://doi.org/10.5817/OS2021-3-9
}

\section{O potřebě komparativního studia}

BUCKOVÁ, M. a kol. (ed.): Reflexia mytologických motívov v duchovnej a materiálnej kultúre národov Ázie, Afriky a Oceánie. Bratislava: Ústav orientalistiky SAV 2019, 243 str. ISBN 978-80-89867-04-2.

Recenzovaná publikace má charakter monografického sborníku, jenž vznikl za podpory grantu VEGA 2/0102/16 „Reflexia kozmologických predstáv v duchovnej a materiálnej kultúre Ďalekého Východu, južnej Ázie a Oceánie“. Jak konstatují editoři svazku (Martina Bucková a Daniela Zhang Cziráková), ${ }^{1}$ tvořily mýty „,neoddelitelnú súčast starovekých náboženstiev. Poskytovali odpovede na otázku, ako vznikol svet, opisovali skutky bohov, zaoberali sa antropogenézou aj eschatológiou. [...] zasahovali do všetkých sfér [...] Mnohokrát poskytovali návod na správne konanie." I proto se tyto „motivy“, resp. bytosti a „narativy“ zrcadlily a nadále (v přetvořené podobě i funkci) projevují $\mathrm{v}$ duchovní i materiální kultuře těchto společenství, v jejich slovesnosti, užitném umění, jazykové ikonografii a reprezentaci, divadle, literatuře apod. a jsou předmětem nejen folkloristického studia.

Autoři se pohybují v prostoru vybraných kultur zemí Blízkého a Dálného Východu, jmenovitě Č́ny, Egypta, Indie, Japonska, Kavkazu, Mezopotámie a Oceánie. Lukáš Pecha ve studii Političtí bohové a božští politici. Náboženství a politika ve starověké Mesopotamii ${ }^{2}$ podává důkaz, že „politika a náboženství prédstavovaly spojené nádoby. Každé božstvo [...] bylo tedy v jistém smyslu politickým činitelem a naopak každý politik (tedy předevšim panovník) měl v sobě cosi božského". 3 Daniela Zhang Cziráková ve studii Drak ako symbol čínskej národnej identity, jeho symbolika a zobrazovanie $v$ čínskom umeni ${ }^{4}$ analyzuje symboliku a zobrazení draka v čínské kultuře různých historických období, mj. také sebeidentifikační představu Číňanů jako potomků draka, a uzavírá, že "porovnanie západného a východného pohladu [na „dragon“ a „long“, pozn. A. M.] dostatočne jasne vysvetlilo kultúrne rozdiely medzi Európou a strednou až východnou Áziou“, kde lze doložit rovněž „stotožnenie draka s cisárom “5 Ivan R. V. Rumánek ${ }^{6}$ ve studii Revenant bórei a jeho vítanie ako návštevníka marebito v ranom

1 BUCKOVÁ, M. a kol. (ed.): Reflexia mytologických motívov v duchovnej a materiálnej kultúre národov Ázie, Afriky a Oceánie. Bratislava: Ústav orientalistiky SAV 2019, s. 1-2.

2 Tamtéž, s. 3-24.

3 Tamtéž, s. 22.

4 Tamtéž, s. 25-29.

5 Tamtéž, s. 58.

6 Tamtéž, s. 60-77. 
kabuki manuskriptov Okuni sóši se detailně věnuje tradičnímu japonskému lyrickému dramatu nó a poetice divadla kabuki a mytologickým pojmům „bórei“ (duch mrtvého) či „marebito“ (návštěvník z onoho světa), a to s využitím čtyř manuskriptů z počátku 17. století.

Sinoložka L’ubica Obuchová nazvala svůj př́íspěvek Čínsky vesmírny program a mytologické názvoslovie ${ }^{7}$ a dokládá, že v posledních třiceti letech jsou pojmenování nových raket, družic a kosmických lodí asociována nikoliv s revolučními tradicemi, nýbrž s tradiční lidovou slovesností, mj. s mýty o bytostech, které na Měsíc cestovaly nebo na něm žijí; tradiční „long“ (drak) je přitom vázán spíše na „silovou sféru“. Funkcemi a významy japonských zviŕ̌ccích mýtů, zvláště hadů, kteří se objevují v císařských kronikách Kodžiki a Nihonšoki (712 a 720 n.l.), se zabývá Zuzana Kubovčáková v př́spěvku Zvieratá v japonských mýtoch a legendách. ${ }^{8}$ Se zaměřením na hadí a dračí mýty ilustruje spojitosti „medzi mytologickými a mocenskými [...] interpretáciami týchto príbehov"9 jejichž jazyk je symbolický a metaforický současně. Martina Bucková se v široce materiálově založené práci Mýtickí stavitelia v Polynézii. Analýza mýtov o „trpasličích lud’och"10 zabývá mýty o bytostech mimořádně zručných v opracováváni kamene a dřeva a tvůrcích mnoha kamenných staveb dodnes patrných. Archeologické průzkumy nálezu kosterních pozůstatků „ludí mimoriadne nízkeho vzrastu"11 na ostrově Flores (2003) však poukazují na nové možnosti explikace těchto mýtů.

Veronika Dubcová ve studii Egyptské hrošie božstvá a ich vzṫah $k$ božstvám a mytologickým postavám starovekého Orientu a východného Stredomoria ${ }^{12}$ a Alžbeta Szomolaiová v práci Džinovia v arabskej a islámskej mytológii a teológii ${ }^{13}$ se věnují mytologii a ikonografii zaměřené na země Předního východu. Jejich bádání je motivované jednak potřebou přinést „nové poznatky o tomto fascinujúcom svete starovekých ludí" (V. Dubcová), jednak potřebou pochopit, proč jsou např. džinové pro muslimy „integrálnou a stále prítomnou súčastou ich jazyka a viery“ (A. Szomolaiová).

Beáta Čierniková ve studii Kult kiahní a iných nákazlivých chorôb u kaukazských národov ${ }^{14}$ detailně rozebírá představy o původu choroby, kultu a rituály léčení neštovic, jejichž božstvo se usídlilo v těle nemocného a toto božství je třeba „uzmierit', zaujat" a uklidnit „rozličnými obradmi, darmi, spevom a tancom“, přičemž příbuzní „nesmeli

\footnotetext{
7 Tamtéž, s. 78-111.

8 Tamtéž, s. 112-143.

9 Tamtéž, s. 112.

10 Tamtéž, s. $144-177$.

11 Tamtéž, s. 144.

12 Tamtéž, s. 178-215.

13 Tamtéž, s. 216-242.

14 Tamtéž, s. 243-254.
} 
prejavovat svoj smútok “15 Indologické bádání pak představuje přehledový výklad Heleny Hadvigové Samskáry - hinduistické prechodové rituály. Výklad základných pojmov a popis jednotlivých rituálov $v$ životnom cykle hinduistu. ${ }^{16}$

Sborník je součástí dlouholetého a cílevědomého úsilí slovenské orientalistiky, která v posledních letech výrazně ovlivňuje i středoevropská studia: připomínáme jen Róberta Gáfrika a jeho monografie Hra s cudzou kultúrou (s podtitulem $K$ recepcii staroindických látok a motívov $v$ nemeckej literatúre) nebo Zobrazovanie Indie $v$ slovenskej literatúre, obě výrazně soustředěné na mezikulturní dialog. Jediné, co textům snad můžeme vytknout, jsou ne vždy důsledně provedené jazykové korektury (chybějící litery, interpunkce, kontaminace a atrakce vazeb aj.). Kniha může jistě sloužit jako vysokoškolská učební pomůcka, jako zdroj informací pro poučené laické publikum z řad pedagogů, lektorů, muzejních a archivních pracovníků, publicistů apod. Ta hlavní, badatelská funkce, ovšem vstupuje do kontextu nejen orientalistických, kulturologických, folkloristických, kulturně areálových a filologických studií, na nichž můžeme „vidiet aj ako dochádzalo $k$ interkultúrnym prienikom či výpožičkám, a ako sa mýty a mytologické bytosti menili v odlišných geografických lokalitách či historických obdobiach “. ${ }^{17}$ Pouze laický pohled na shody a odlišnosti podob a charakterů ,trpasličích lidí v polynéských mýtech a mýtech evropských, slovanské nevyjímaje, na spíše pozitivní (či alespoň ambivalentní) roli draka (long) v mytologii čínské, japonské, ale i vietnamské etc. a na jejich protějšky v pohádkách, pověstech a legendách tzv. západních, včetně slovanských, na dramatickou roli „duchů mrtvých“ v japonském (či obecně asijsko-pacifickém) prostoru a ve folklóru a umění středoevropském, na využití mytologických postav a př́iběhů v soudobém názvosloví čínském či indickém a v „našem“ zábavním průmyslu či ikonografii, ukazuje na souvislosti zdaleka nejen kontrastivně typologické a genetické, které by neměly zůstat opomíjeny.

Sborník ukazuje, že respekt $\mathrm{k}$ historicitě a ,jinakosti“ stejně jako vůle $\mathrm{k}$ jejímu autonomnímu poznání a především pochopení předpokládají ruku v ruce odmítnout dogma prevalence jednoho kulturně civilizačního okruhu (na prvním místě jazyka a pojmové axiologie) a znamenají, že bychom neměli vnášet minimálně do estetické a mytologické struktury jiných kultur jim neadekvátní hodnocení, jakkoli domněle nadřazená, tzv. univerzalistická.

Alexej Mikulášek

15 Tamtéž, s. 243.

16 Tamtéž, s. 255-268.

17 Tamtéž, s. 2. 


\section{Literatura:}

BUCKOVÁ, M. a kol. (ed.): Reflexia mytologických motívov v duchovnej a materiálnej kultúre národov Ázie, Afriky a Oceánie. Bratislava: Ústav orientalistiky SAV 2019, 243 str. ISBN 978-80-89867-04-2.

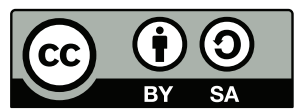

Toto dílo Ize užít v souladu s licenčními podmínkami Creative Commons BY-SA 4.0 International (<https:// creativecommons.org/licenses/by-sa/4.0/legalcode>). Uvedené se nevztahuje na díla či prvky (např. obrazovou či fotografickou dokumentaci), které jsou v díle užity na základě smluvní licence nebo výjimky či omezení príslušných práv.

https://doi.org/10.5817/OS2021-3-10

\section{O funkcii literatúry ako existenciálnej komunikácie}

HAJKO, D.: Literatúra ako existenciálna komunikácia. Bratislava: VSSS, 2019, $167 \mathrm{~s}$. ISBN 978-80-8202-103-8.

V poslednom období sa začala objavovat’ rada nových komunikačných prostriedkov, čím vzrástol záujem o nové možné spôsoby komunikácie, na ktorú sa postupne začalo pozerat’ ako na samostatný predmet vedeckého výskumu. Jej klasické formy (písomná, verbálna, vizuálna, neverbálna, ...) sú dnes už pomerne detailne spracované a do pozornosti sa postupne dostávajú úzko špecializované typy komunikácie, akou je napríklad existenciálna.

V súčasnej slovenskej literárnej vede sa práve tomuto typu komunikácie venuje Dalimír Hajko, ktorý pracuje na Filozofickej fakulte Žilinskej univerzity. Jeho monografická publikácia Literatúra ako existenciálna komunikácia, vydaná na konci roku 2019, je venovaná skúmaniu vzájomných súvislostí medzi tvorbou umeleckej literatúry (poézie a prózy), literatúry faktu a filozofickými úvahami.

Prvá čast' monografie sa zaoberá všeobecnými teoretickými a metodologickými východiskami. Pojem existenciálna komunikácia je interpretovaný ako typ komunikácie, na základe ktorej dokáže človek vysvetlit’ opodstatnenost’ svojej existencie nemá teda iba akési formálne príznaky, ale skrýva hlbší odkaz. Autor pridáva vlastné komentáre $\mathrm{k}$ danej téme a neskôr prechádza do oblasti literatúry, ktorú využiva ako príklad na vysvetlenie prenosu nielen informácií, ale aj etických hodnôt na čitatela.

Zaujímavým prvkom monografie je porovnávanie vedeckej a umeleckej literatúry, v ktorom autor vychádza z tézy o ich podobnostiach a vzájomnej prepojenosti, 